\title{
List of Illustrations, Tables, and Figures
}

\section{Illustrations}

Frontispiece: William Heberden (1710-1801). Mezzotint by J Ward after Sir W Beechey. (Wellcome Library, London.)

1. Cattle roaming on common land. Etching by P Potter, 1643 . (Wellcome Library, London.)

2. A cow grazing on public lands. Barbados (photograph: L Michaels).

3. A fat judge admiring a fat bullock. Etching by James Gillray, $c .1802$. (Wellcome Library, London.)

4. Two prize winning Leicester rams. Etching by H Beckwith, c. 1849, after H Strafford. (Wellcome Library, London.)

5. Award winning Middlesex pigs, bred and fed by $\mathrm{Mr}$ Wm Mills Barber of Uxbridge. December 1848. Etching by E Hacker, $c$. 1848, after H Strafford. (Wellcome Library, London.)

6. Simon Fraser, Lord Lovat (1667-1747). Etching after W Hogarth (from the collection of Ronald Paulson, reproduced with permission).

7. A vision of the first of Mayor of London appears to feasting aldermen to warn them against luxury. Etching by Thomas Rowlandson, 1809. (Wellcome Library, London.)

8. 'A Voluptuary under the horrors of Digestion'. The Prince of Wales lingers over a meal at Carlton House. Caricature by James Gillray, 1792. (@ Copyright The British Museum.)

9. The beam scale at Berry Brothers and Rudd Ltd. (Reproduced with permission.)

10. Emperor Trajan (c. 53-117), from a sculpture in the Museum of Anatolian Civilisation, Ankara, Turkey. The earlobe cleft is clearly visible. (Photograph by Professor James Russell, reproduced with permission.) 


\section{Illustrations, Tables and Figures}

11. 'Okay, will somebody please bring me up to date?' (Arnie Levin, cartoonist). (Reproduced from the New Yorker collection, 29 January 1996. From cartoon bank with permission.)

\section{Tables}

I.1 Male manifestations of coronary heart disease. Framingham Study.

I.2 Physical inactivity and risk of coronary heart disease.

II.1 Causes of death, from London Bills of Mortality, last three weeks of 1700 .

III.1 Some classical era notables living to beyond age 60.

III.2 Some records of inscriptions of age at death on Roman empire monuments.

III.3 Total population of England in the eighteenth century. 31

III.4 Average height of military recruits, 1747-97. 33

III.5 Eighteenth-century infant and childhood mortality. 34

III.6 Adult mortality in England and France, 1740-1809. 37

III.7 Expectation of life at birth, 1650-1774. 37

III.8 Number of English upper- and middle-class families, 1688.

III.9 Number of English upper- and middle-class families mideighteenth century.

IV.1 Average weight of animals sold at Smithfield, 1710-90. 49

IV.2 Comparison of controls with animals managed in special feed lots. $\quad 53$

IV.3 Five-year average cattle and sheep sales at Smithfield, 1732-96. 54

IV.4 Absolute and relative risk of death according to use of wine, beer or liquor.

V.1 Fatty acid composition of muscle as percentages: wild and farmed animals and birds.

V.2 Effect of varying PUFA as percentage of constant total fat intake. Lipid profile at beginning and end of trial.

V.3 Relation of CHD deaths to diet and serum cholesterol levels. Helsinki heart study.

V.4 Serum cholesterol status and coronary artery responsiveness.

V.5 Average systolic blood pressures: Japanese and American applicants for life insurance.

V.6 Age adjusted death rates per 10,000 person-years according to baseline fish consumption.

V.7 English arable cereal yields, 1750-1800.

V.8 Human studies evaluating oat products and lipid effects.

V.9 Relationship between fibre intake tertiles and male CHD mortality expressed as relative risk males.

V.10 Comparative effects of starch and sugar intake on lipid profile. $\quad 85$

V.11 Coffee consumption, serum cholesterol and CHD mortality. 94 


\section{Illustrations, Tables and Figures}

V.12 Relative risks of death from coronary heart disease according to coffee consumption.

V.13 Comparative effects of 4 week consumption of boiled and unfiltered or boiled and filtered coffee on serum lipid profile.

V.14 Coffee consumption and coronary heart disease: male subjects.

V.15 Relationship between relative weight and cardiovascular disease incidence.

VI.1 Male CHD death rates per 100,000 person years: non-smokers and pipe smokers.

VI.2 Exercise duration to angina. Effect of exposure to tobacco smoke.

VI.3 Relative risks associating ischaemic heart disease morbidity and mortality with passive cigarette smoking.

VII.1 Average weights of male members of the English nobility in the eighteenth century.

VII.2 Weights of male wine store patrons, 1765-80. 118

VII.3 Relationship between fibre intake and blood pressure. 120

VIII.1 Ischaemic heart disease average annual mortality per 100,000 male residents of south-east English counties, 1959-63.

VIII.2 Ischaemic heart disease mortality among Norwegian men, 1966-70.

VIII.3 USA male urban and rural mortality, 1959-61.

VIII.4 First disabling CHD event. Bell System staff aged 30-59 at entry to study.

VIII.5 Ten-year CHD mortality percentage among British civil servants.

$\begin{array}{lll}\text { IX.1 } & \text { Five-year incidence per 100 of CHD in London bus crews. } & 138 \\ \text { X.1 } & \text { Risk factors: British white and Asian patients. } & 145\end{array}$

X.2 Nutrient intakes in Asian households compared with national food survey.

X.3 Nutrient intake and serum lipid levels of Japanese resident in Japan or California.

X.4 Regression coefficient between saturated fat intake and serum cholesterol.

X.5 Biochemical risk factor profile: British Asian and white patients. 148

X.6 Comparison of aspects of risk factor profile. Exercising British Asian and white coronary heart disease patients.

X.7 Biochemical physical features. South Asian and North European patients and their sons free of CHD.

XII.1 Annual mortality per million from diseases of the circulatory system and dropsy.

$\begin{array}{ll}\text { XII.2 England and Wales population growth. } & 165\end{array}$

XII.3 United Kingdom meat imports. 166

XII.4 Cis- and trans-fatty acids as a percentage of the fats in the diet and the total diet. 


\section{Illustrations, Tables and Figures}

XII.5 Effect of soft and hard margarines on the lipid profile.

XII.6 Cigarette tobacco consumption in the United Kingdom during the twentieth century.

\section{Figures}

V.1 Fatty acid composition of free living woodland buffalo and domestic beef compared.

V.2 Correlation between average intake of saturated fats and 25-year mortality from coronary heart disease (percentage) in the Seven Countries study.

V.3 Correlation between total serum cholesterol level and acetylcholine induced dilator capacity of the coronary system.

V.4 Mean levels of serum total cholesterol, LDL, HDL and triglycerides before, during and after supplementation with lipidrich coffee filtration fraction.

V.5 26-year incidence of cardiovascular disease by Metropolitan Life Insurance Co. relative weight.

VII.1 Relation of age changes in blood pressure to daily sodium excretion as a reflection of salt intake.

VIII.1 Variations in Middlesex land registry deed values and yields on consols, 1731-1800.

VIII.2a. Correlation between mortality from arteriosclerotic heart disease, 1964-67, in men aged 40 to 69 years and infant mortality rates, 1896-1925.

VIII.2b. Correlation between mortality from arteriosclerotic heart disease, 1964-67, in women aged 40 to 69 years and infant mortality rates, 1896-1925.

XI.1 Incidence of CHD per 1000 subjects over a 6-year follow-up in relation to triglyceride and cholesterol levels.

XII.1 Association between average intake of trans-fatty (elaidic) acid and 25-year mortality rates from coronary heart disease (\%) in the Seven Countries study.

XII.2 Non-valvular heart disease mortality in men, 1931-71, by age and social class. 